News, Notes and Queries

NINTH BRITISH CONGRESS ON THE HISTORY OF MEDICINE (1973)

THE British Society for the History of Medicine will be holding its Ninth Congress on the History of Medicine between 4 and 8 September 1973 in Wales. The two principal themes of the Congress will be 'The History of Industrial Disease' and 'Wales and Medicine'. A programme of specialist speakers is being arranged for the historical sessions as well as short papers from members.

For full details, please write to Dr. John Cule, Abereinon, Capel Dewi, Llandysul, Cards.

\title{
HISTORY OF MEDICINE SOCIETY OF WALES
}

THE first meeting of the History of Medicine Society of Wales was held on 14 November 1972 at the Anatomy School University College, Cardiff. The Provost of the Welsh National School of Medicine, Dr. J. P. D. Mounsey, introduced the new film 'William Harvey and the circulation of the blood', which has recently been made for the Royal College of Physicians.

Meetings are being arranged during each academic term, preceded by light refreshments. Further details of the Society are available from the Honorary Secretary, Prof. J. D. Lever, Department of Anatomy, University College, P.O. Box 78, Cardiff CF1 1XL.

\section{UNIVERSITY OF BIRMINGHAM SOCIETY FOR THE HISTORY OF MEDICINE}

THE inaugural meeting of this society was held on 25 October 1972. Sir Arthur Thomson had very kindly agreed to become the society's first president, and the following committee members were elected: Chairman, Dr. B. T. Davis; Secretary, Dr. H. A. Waldron; Treasurer, Dr. J. Hatch, Committee Members: C. Clark and R. A. Cohen. The society will hold not less than two meetings in each academic term at which papers will be read and discussed. The annual subscription is $\mathrm{fl}$. Anyone interested in joining the soceity should contact the Secretary in the Department of Social Medicine.

\section{SYMPOSIUM IN HONOUR OF RICHARD H. SHRYOCK}

RICHARD H. SHRYOcK will be honoured during a day-long symposium to be held on 7 April 1973. The meeting is being organized by Prof. G. B. Risse of the Department of the History of Medicine, in collaboration with the History Department and Shryock's long-time friend, Prof. Merle Curti. Mrs. R. H. Shryock is expected to attend. The papers to be presented will deal with various topics of American social medical history in Prof. Shryock's tradition. 